\title{
Medicolegal
}

\section{The Gee case: the BBC continues alone}

\author{
CLARE DYER
}

At the request of $\mathrm{Mr}$ Charles Gray QC, leading counsel for $\mathrm{Dr}$ Clemency Mitchell and Dr Roger Blackwood, Lord Justice CroomJohnson ordered last week that the trial of Dr Sidney Gee's libel action against the two doctors would be stayed until after the disposal of the action against the BBC. This means that the two doctors drop out of the picture for the moment and the trial continues with only the BBC defendants.

Before the trial began Dr Gee's three separate actions-the first against the BBC and members of the That's Life team, the second against Dr Blackwood, and the third against Dr Mitchell-had been consolidated for hearing in a single trial. Mr Gray said that in asking for "deconsolidation" halfway through the trial he accepted that he was making a novel application. His Lordship commented that this was a novel libel case. One of the major reasons for his application, Mr Gray said, was the appalling financial consequences of his clients' continued participation in the trial. The divergence between the BBC's case and his clients' case had become much greater than had been expected when the trial began. It was unlikely to end before the end of July at the present rate of progress, and there must be many weeks of evidence in which his clients and their counsel and solicitors would have no part to play at all. Once judgment in the BBC action was given it was his clients' and Dr Gee's intention to look at the judgment with care, and with good will and good sense it was likely that it would be possible to reach some sort of accommodation. He emphasised, however, that Dr Blackwood and Dr Mitchell were not resiling from their position in defending the action.

Before the order was made the court heard evidence from $\mathrm{Dr}$ Gee's second expert witness, Dr Charles Edmonds, consultant physician and endocrinologist at Northwick Park Hospital, clinical scientist at the Clinical Research Centre of the Medical Research Council at Harrow, and consultant physician in charge of the thyroid therapy clinic at University College Hospital, London. Dr Edmonds told the court that he had had published more than 100 scientific and medical papers and books and was currently scientific editor of the journal Endocrinology. He said his main interests were in thyroid disease and the endocrine control of various aspects of metabolism.

Dr Edmonds said he was personally familiar with the effects of administering thyroid to patients-both replacement doses for those whose thyroid gland was functioning inadequately and suppressive doses for patients with cancer of the thyroid. He had had several hundred patients over the years taking relatively high doses of thyroxine.

In answer to questions put by Michael Beloff QC, Dr Gee's leading counsel, about the allegations in the BBC programme $\mathrm{Dr}$ Edmonds said he did not agree that Dr Gee had put Mrs Day's life in danger. He did not accept that the medicines provided for Mrs Day were dangerous in the doses in which they had been provided. He

London NW1

CLARE DYER, BA, BLS, solicitor and legal journalist had seen no evidence of early heart disease in any of the papers concerning Mrs Day. Her blood glucose curve was entirely normal, so diabetes mellitus was ruled out. He added that he thought that the diagnosis of diabetes had been made on the basis of urine glucose, which was not acceptable now.

He said he did not think there was any evidence in published work that a dose of Dexedrine of the size given by Dr Gee had ever killed anybody. If it was established that Mrs Day suffered from the symptoms alleged he thought it was very unlikely to be due to $\mathrm{Dr}$ Gee's treatment. He thought the BBC's case that no competent doctor would supply $250 \mathrm{mg}$ thyroid extract a day in the treatment of obesity was untenable, he continued. The British Pharmaceutical Codex, 1979 edition, stated: "The usual dose of thyroid is 30 to $250 \mathrm{mg}$ daily"; it was unlikely that the Pharmaceutical Society of Great Britain would recommend a dose that was toxic.

Papers on the use of thyroid hormones in obesity had been published in recent years, many from very reputable authorities, he said. The results of a trial using triiodothyronine in 20 obese patients had been published in Clinical Endocrinology in 1981. One of the coauthors was Professor Sir Raymond Hoffenberg, currently president of the Royal College of Physicians and an eminent thyroidologist. Professor Ivor Mills of Cambridge had had an article published in the Lancet, and an article by a German group on the use of triiodothyronine had been published in the International fournal of Obesity in 1983.

With regard to the proposition that the weight loss produced by the thyroid extract resulted from catabolism of the lean tissue, Dr Edmonds said that that was a dose dependent phenomenon. A person had to have plasma triiodothyronine concentrations higher than about 4-5 nmol/ $/ \mathrm{night}$ and morning for some period before catabolism reduced lean body mass. He would not have expected $250 \mathrm{mg}$ thyroid hormone a day to result in catabolism of lean tissue.

Dr Edmonds cited several studies to show that obese patients were more tolerant of exogenous thyroid hormone than those of average build. He had combed the studies of obese patients given thyroid hormones and from nine studies over the years 1959 to 1983 he had culled 200 patients, and the only significant side effect was atrial fibrillation in one patient taking $225 \mu \mathrm{g}$ triiodothyronine daily. Even if for the sake of argument one assumed that a patient was rendered thyrotoxic by the administration of thyroid extract, although thyrotoxicosis was an unpleasant disease and potentially a dangerous one it nevertheless rarely presented a threat to life, he added.

With regard to Mrs Day's alleged heart problem, Dr Edmonds said that there was no evidence of heart disease in the investigations carried out. But the medical certificates provided by her general practice when she was off work diagnosed a cardiac problem. He said a classic account by Paul Wood pointed out that once people's attention was directed to their heart and they had anxiety about it it was very difficult to get rid of the pain. Mrs Day had many features of the neurotic picture that Paul Wood described.

Moving on to Mrs Falconer, Dr Edmonds said there was no means of necessarily relating the tablets to the obvious heart disease that she had. Had she gone into atrial fibrillation, rather than ventricular fibrillation, he would have been much more suspicious 
about it. He did not think there was any connection between the treatment and the death; this was the type of thing that could happen to anybody with coronary artery disease. In Mrs White's case the case was not at all firm that she was made thyrotoxic or that the treatment caused or contributed to her death.

Cross examined by Mr Andrew Rankin QC, leading counsel for the BBC, Dr Edmonds said he did not know that Dr John Garrow of Northwick Park Hospital, one of the leading world experts on obesity, had condemned Dr Gee's treament as dangerous. Asked by Mr Rankin whether the fact that Professor Reed Larsen, a world authority on thyroid, would be coming from Harvard to tell the court that he thought Dr Gee's treatment was dangerous caused him to reflect on the views he had expressed, Dr Edmonds replied that his views were based on published work and his analysis of the treatment. Asked whether he knew that Dr Garrow had changed his mind in the mid-1970s about the usefulness of thyroid hormones in treating obesity and had canvassed against it since, Dr Edmonds responded that he was sure that Dr Garrow had done studies more recently, because an assistant of his who was using triiodothyronine had given a talk less than two years ago about its use.

Mr Rankin said that Professor James, Dr John Munro, and Professor Yudkin would all tell His Lordship why the treatment was dangerous in their opinion. Dr Edmonds replied that if they could provide evidence then he would be convinced.

With regard to Dr Garrow's views, Dr Edmonds said that in 1981 a paper cowritten by Dr Garrow on the rate of protein turnover in obese women had been published in the proceedings of the Nutrition Society. The patients were 10 obese women, of whom three had received $120 \mu \mathrm{g}$ triiodothyronine daily, well above $\mathrm{Dr}$ Gee's dose; and three had received $25 \mathrm{mg}$ thyroxine daily. $\mathrm{Dr}$ Garrow would not under any circumstances place patients at risk, and the study had been passed by the Northwick Park Hospital ethical committee. Professor Mills's group at Cambridge had had an article published in the Lancet in 1980 entitled treatment of obesity with triiodothyronine. Eight patients had been given $60 \mu \mathrm{g}$ triiodothyronine daily.

\section{Medicine and the Media}

$\mathrm{T}$ HE LATEST cancer cure story, which started in the London Standard (28 February), was as inflated as the headline that led it off. "Cancer: new hope of cure," said the front page of the paper in letters $13 / 8$ inches high. The article began: "A dramatic development in cancer treatment could save thousands of lives." Later an official from the City of Hope Medical Center in Los Angeles, Bonnie Rogers, was quoted as saying, "If they are as successful as in the lab we are talking about a genuine cancer cure."

For anybody familiar with assessing medical reports the information was there in the article that this was far from being a "genuine cure." The story was about tissue necrosis factor which has destroyed "massive cancer tumours" in mice but which has not been used in man. Dr Charles Todd, the head of immunology at the hospital, said, "I'm very cautious about saying this is the big hope we have been looking for. . . ." But the reporters couldn't resist inserting, "If the doctor's hopes are realised deaths from lung cancer could become a thing of the past." Finally, the exuberant Mrs Rogers was quoted again: "Cancer could be eradicated within five years."

The rest of the media immediately went on cancer cure alert. But they were well prepared: news editors have experienced far more cancer breakthroughs than cancer researchers. But they must go through the ritual. The Guardian's experienced medical correspondent, Andrew Veitch, was presumably summoned by the news desk, and he could hardly suppress in his report the next day the tedium he felt with the Standard's belated discovery of tissue necrosis factor: "Bioengineers ... . isolated and cloned the human gene which codes for tumour necrosis factor two months ago. Their success was reported in Nature and the Guardian on 20 December. . . . The factor was discovered at least 10 years ago and described by the Cambridge scientist Dr Abraham Karpas in 1977."

The Times made it clear that the force of the Standard's story was a report in that week's issue of Nature (28 February) of the production by genetic engineering of human tissue necrosis factor. The popular press wasn't clever enough to know the source of the story, but it was circumspect enough to demote the story in size and prominence. The Daily Star, which was the only paper not to move the story on, gave it only one inch on page 2, while the Sun, the Daily Mirror, and the Daily Express not only gave it little prominence but also had statements from the British doctors calling for caution. Indeed, the Sun quoted a spokesman from the Imperial Cancer
Research Fund as saying: "It's cruel to give thousands of people the impression that a miracle cure is just around the corner." Amen. - RICHARD SMITH, assistant editor, London.

$\mathrm{A}$ NYBODY WHO sets out to educate on alcohol and its problems has one particular problem to overcome-the idea that most of us have (including those of us with real drink problems) that we drink harmlessly and it is those people over there (let's call them alcoholics) who have problems. Even if you set out specifically to reach problem drinkers you are likely to be ignored by much of your potential audience, but the difficulties are much greater if you are aiming at all those who drink ( $90 \%$ of the English) and who therefore may run into problems.

Marcus Grant in Same Again: a Guide to Safer Drinking ( $£ 1.95$, Penguin) is aiming at "everybody who is interested in their own drinking or in the drinking of somebody else," and he spells out in the third paragraph that "Nobody who drinks even a small amount is immune to the problems which alcohol can cause." In contrast, Jo and Jonathan Chick in Drinking Problems: Information and Advice for the Individual, Family and Friends ( $£ 1 \cdot 75$, Churchill Livingstone) aim at "people with drinking problems, and those who are worried about their drinking or who have friends or relatives who complain about it." Even they, however, avoid the dangerous word alcoholic, forgetting perhaps that most people still use the word and want to know more than anything "whether or not I am an alcoholic." Grant explains why he avoids the word and gives a neat history of the rise and fall of the concept of the alcoholic.

The problem for Grant is that people are likely to buy a book on drinking only when they are beginning to think that they may have a problem, and by that stage the chances are that they have a serious problem. Such a person looking for direct help may be frustrated by Grant's long descriptions of patterns of drinking despite the fact that education on such topics may well produce the richest rewards in reducing alcohol problems. But if the reader looking for help presses on he or she will come to some useful and practical advice, which is to be found also in a more condensed form in the Chicks' book.

One thing that the reader will not find in the Chicks' book, however, is advice on safe limits. They ask and answer the question "Am I drinking too much?" and they give information on the 